rescidioc

\section{Age and Gender Association of Class III Malocclusion among Subjects Reporting to a University Hospital in Chennai City - A Retrospective Study}

Research Article

Jitesh $\mathrm{S}^{1}$, Dr. Ravindra Kumar Jain ${ }^{2 *}$, Dr. Madhu Laxmi M³

${ }^{1}$ Saveetha Dental College and Hospitals, Saveetha Institute of Medical and Technical Sciences, Saveetha University, Chennai 600077, Tamil Nadu, India. ${ }^{2}$ Associate Professor, Department Of Orthodontics, Saveetha Dental College and Hospitals, Saveetha Institute of Medical and Technical Sciences, Saveetha University, Chennai 600077, Tamil Nadu, India.

${ }^{3}$ Professor, Department of Oral and Maxillofacial Surgery, Saveetha Dental College and Hospitals, Saveetha Institute of Medical and Technical Sciences, Saveetha University, Chennai 600077, Tamil Nadu, India.

\title{
Abstract
}

\begin{abstract}
Malocclusion is a misalignment or incorrect relation between the teeth of the two dental arches when they approach each other as the jaws close. Class III malocclusion is skeletally characterized by an overgrowth of the mandible (mandibular prognathism), an undergrowth of the maxilla (maxillary deficiency), or a combination of both. The aim of this study was to assess the age and gender association of Class III malocclusion in the outpatient population visiting a Private Dental college. This was a retrospective study done using case records of the outpatient population visiting a Private Dental college. Out of 86,000 patients who reported to dental college, 269 patients who had Class III malocclusion were included in the study. Data about type of class III and other associated factors was recorded and tabulated. Analysis of the data was performed using SPSS version 20. Descriptive statistics and Chi square tests were done. The male predominance $(65.8 \%)$ was noted. Almost equal distribution among dental $(53.5 \%)$ and skeletal $(46.5 \%)$ was noted. Skeletal class III was more common in Adolescents and children compared to dental class III whereas dental Class III was common in adults. There was no statistically significant association between gender and class III malocclusion $\mathrm{p}$ value $>0.05$ and a statistically significant association was found between age group and type of class III malocclusion. Class III malocclusion was most commonly reported in the 19-30 years age group, $\mathrm{P}$ value $<0.05$.Within the limits of the present study, class III malocclusion was more prevalent in males than females and skeletal class III malocclusion was most common in children and adolescents whereas dental class III was common in Adults.
\end{abstract}

Keywords: Dental; Malocclusion; Skeletal.

\section{Introduction}

Angle classification has prevailed over the last century as a simple, quantifiable method to test malocclusion prevalence within populations. However, what Angle defined as a "normal occlusion" should, in fact, be considered the "ideal" occlusion given the strict criteria he used in his classification. This ideal occlusion is rather uncommon and has driven researchers to disagree on how much deviation from the ideal should be accepted as normal $[1,2]$.

Class III malocclusion is characterized by an overgrowth of the mandible (mandibular prognathism), an undergrowth of the maxilla (maxillary deficiency), or a combination of both $[3,4]$ The prevalence of Class III malocclusion has been described between
$1 \%[5,6]$ to over $10 \%$ [7], depending on ethnic background [5, $6]$, sex [7, 8] and age [9]. It has been reported that approximately $75 \%$ of Class III cases in male Caucasians have a skeletal origin and are a result of mandibular prognathism or macrognathia $[10,11]$. The prevalence of Class III malocclusion among Caucasian people ranges from $0.48 \%$ to $4 \%[5,12,13]$. But compared to Caucasian people the prevalence of class III malocclusion is higher in Japanese population. It rises as high as $10 \%[14,15]$ Diagnosis and treatment of class III malocclusion are choked up with contradiction in the type, timing and duration of treatment. To know the exact aetiology of any dentofacial characteristics genetic evaluation is mandatory. The effects of genetic association in orthodontic treatment are poorly understood $[16,17]$.

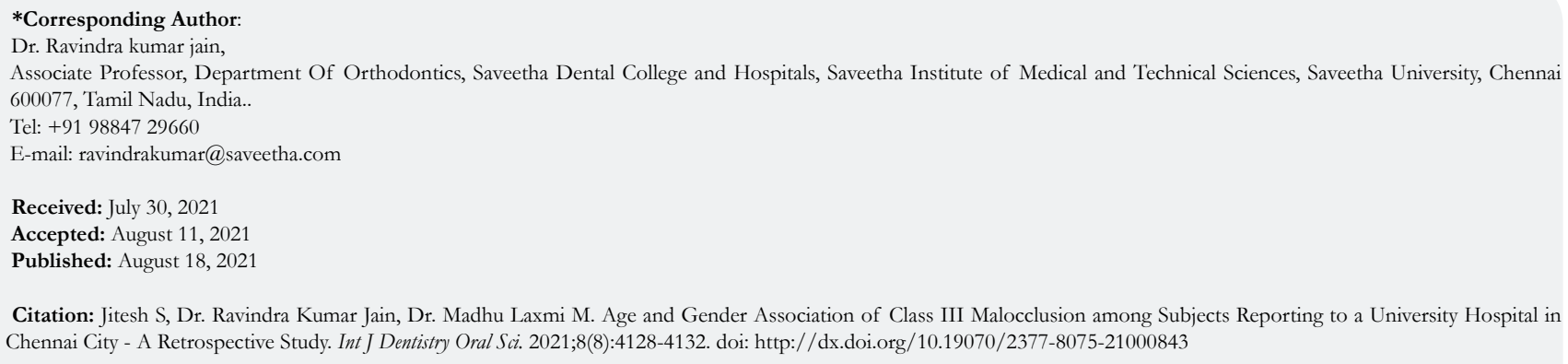

Copyright: Dr. Ravindra kumar jain ${ }^{\circ} 2021$. This is an open-access article distributed under the terms of the Creative Commons Attribution License, which permits unrestricted use, distribution and reproduction in any medium, provided the original author and source are credited. 
Although there has been extensive literature concerning the genetic basis of the dentofacial abnormalities and malocclusions, data provided by these studies were quite sparse $[18,19]$. Furthermore, surveys dealing with genetics constituted only $0.5 \%$ of the total in orthodontic journals since the 1980's [20, 21]. To date, many investigations have focused largely on treatment modalities and outcomes, with little being accomplished toward an understanding of the aetiology of class III phenotype and potential relationship between the genetic components or how genetic factors may influence the response to treatment [22]. In spite of the continually increasing data on malocclusion prevalence, little has been done to consolidate this information in a comprehensive and critical way $[23,24]$. Although no protocol has been enacted governing the methods of Angle class III malocclusion prevalence studies, a review and meta- analysis of the available literature will be helpful in establishing guidelines for future researchers [25]. Previously our team has a rich experience in working on various research projects across multiple disciplines [26, 40]. Now the growing trend in this area motivated us to pursue this project.

The aim of this study was to assess the age and gender association of Class III malocclusion in the outpatient population visiting a Private Dental college.

\section{Materials and Methods}

\section{Study design and Study setting}

The present hospital-based retrospective study was carried out using digital case records of 269 patients who reported with Class III malocclusion from 86,000 patients attending the dental college from June 2019 to march 2020 seeking orthodontic treatment. Ethical clearance to conduct this study was obtained from the scientific Review Board of the hospital (SDC/SIHEC/2020/DIASDATA/0619-0320).

\section{Sampling}

Case records of 269 patients who reported with Class III malocclusion were included in the study. Inclusion criteria was patients with class III malocclusion visiting the dental college in the specified period of time, patients referred for orthodontic correction of Class III malocclusion. Cross verification of the data for errors was done. Each case was verified for the general information of the patients, whether its skeletal or dental malocclusion was identified using the diagnosis mentioned in the case records and clinical photographs. The exclusion criteria was other malocclusions and missing or incomplete data.

\section{Data collection and Tabulation}

Exclusion criteria eliminated cases that had other malocclusions; cases with no clinical photograph and cases that were not approved by the concerned faculty in the hospital. A single calibrated examiner evaluated the clinical photographs of 269 patients and graded them based on skeletal and dental malocclusion. Data was tabulated in excel and was imported to SPSS where the variables were defined.

\section{Results \& Discussion}

IBM SPSS version 20 was used for statistical analysis. Descriptive analysis of the age group, gender, type of class III distribution was done. Chi - square test was done for association between age, gender and type of Class III. Results were tabulated and represented graphically. A male dominance $(65.8 \%)$ over females (34.2\%) was noted (Figure 1). In the type of Class III malocclusion, almost equal distribution among dental (53.5\%) and skeletal $(46.5 \%)$ was noted(Figure 2$)$. There was no statistically significant association between gender and class III malocclusion (Chi square value $-.934, \mathrm{DF}-1, \mathrm{p}$ value $=0.33(>0.05)$ ) (Figure 4$)$ and a statistically significant association was found between age group and type of class III malocclusion it was most commonly

Figure 1. Bar graph depicting gender distribution of the Class III malocclusion. $\mathrm{X}$ axis represents the gender and $\mathrm{Y}$ axis represents the percentage of the subjects in the present study; 177(66\%) males, 92(34\%) females.

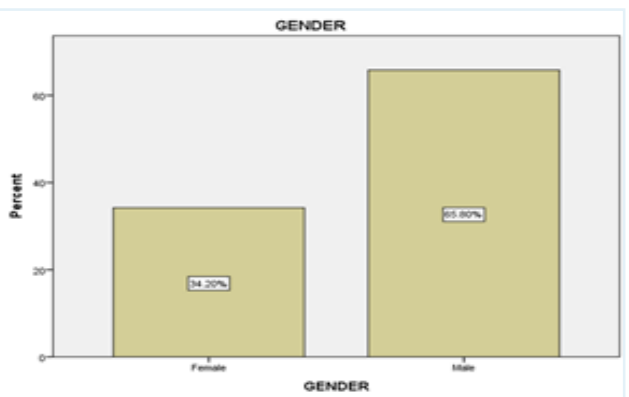

Figure 2. Bar graph depicting the Classification of Class III malocclusion. $\mathrm{X}$ axis represents the type of malocclusion and $\mathrm{Y}$ axis represents the percentage of the subjects in the present study; 125(46.5\%) skeletal and 144(53.5\%) dental Class III malocclusion.

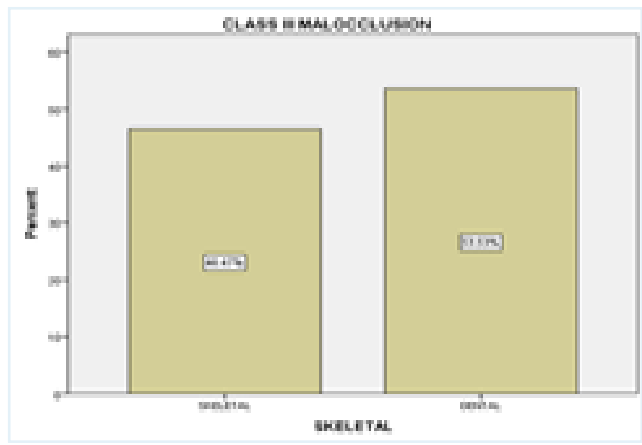


Figure 3. Bar graph representing the association between age groups and the type of Class III malocclusion. $\mathrm{X}$ axis represents the age group and $\mathrm{Y}$ axis represents the number of subjects with class III malocclusion. Chi square association was done and found to be significant. Pearson's Chi-Square value $-15.797, \mathrm{DF}-2, \mathrm{P}=0.01(<0.05)$, Statistically significant proving age association, both types of class III malocclusions were common in the age group of 19-30 yrs when compared to the other age groups.

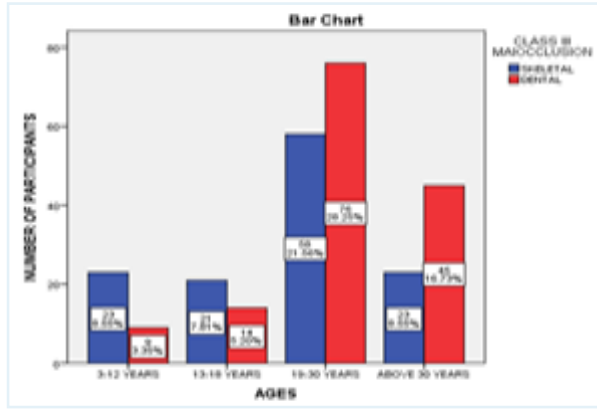

Figure 4. Bar graph representing the association between the gender and the type of Class III malocclusion. $\mathrm{X}$ axis represents the gender and $\mathrm{Y}$ axis represents the total number of participants. More number of males reported with class III malocclusion. Association was tested by Chi square test and was found to be non-significant. Chi square value $-.934, \mathrm{DF}-1$, p value $=0.33(>0.05)$ statistically not significant, hence class III malocclusion was not associated with gender.

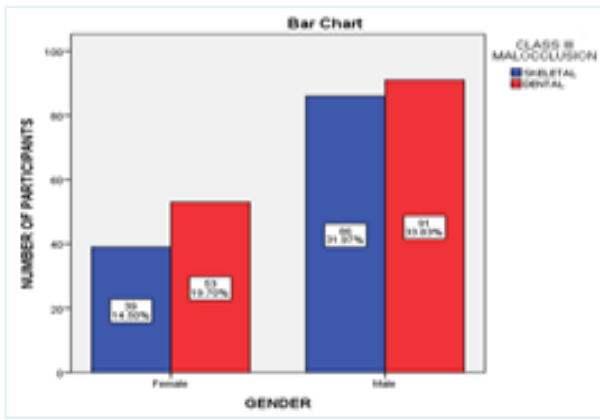

reported in the 19-30 years age group (Pearson's Chi-Square value - 15.797, DF-2, P = $0.01(<0.05)$ )(Figure 3). Skeletal class III was more common in adolescents and children whereas dental Class III was common in adults compared to skeletal. (Figure 3).

This study shows that in class III malocclusion $65.8 \%$ were more prevalent in males than females $(34.2 \%)$. Out of 269 subjects with class III malocclusion, 125 (46.5\%) were skeletal and $155(53.5 \%)$ were dental malocclusion .Skeletal class III malocclusion was most common in children and adolescents, whereas dental class III was common in Adults.

Onyeaso et al.(41)who reported that males were found to have significantly more of classes II and III molar relationships than females which supports this study where as Baccetti et al reported that females were found to significantly more of classes III molar relationships than females which contradicts our study study (42). From other articles, Chinese and Malaysian groups showed a much higher mean prevalence rate than other racial groups: $15.69 \%$ and $16.59 \%$, respectively [43-45]. This is consistent with previous reports of higher rates of Angle class III malocclusion among Asian populations.

Baccetti et al reported that Class III malocclusion is associated with a significant degree of sexual dimorphism in craniofacial especially after the age of 13 and female subjects with Class III malocclusion present with significantly smaller linear dimensions in the maxilla, mandible, and anterior facial heights when compared with male subjects during the circumpubertal and postpubertal periods which supports our study[42].

Angle class III malocclusion rates among the three Middle East- ern groups in this study are fairly similar. However, previous studies indicated a wide range of rates from $1.3 \%$ in Israeli Arabs to $15.2 \%$ in Iranians [46-48]. Additionally, many different rates appear forIranians: $2.1 \%, 7.8 \%, 9.2 \%$, and $15.2 \%$ [49]. However, a 1969 study of Egyptians [50] showed a rate of 4\%. Agreement of previously reported Angle class III prevalence data appears to be haphazard at best among Middle Eastern populations. Furthermore, major discrepancies appear to exist among populations within individual countries.

Our institution is passionate about high quality evidence based research and has excelled in various fields [51-61]. We hope this study adds to this rich legacy.

The limitation in this study is its smaller sample size. A similar study should be conducted on a larger scale involving a large number of samples and twins for more reliable results. Hence, further extensive studies should be done in this field of research.

\section{Conclusion}

Within the limits of the present study, class III malocclusion was more prevalent in males than females but no significant difference was noted. Both skeletal class III malocclusion and dental class III were most common in the age group of 19-30 yrs and in children skeletal class III was more common than dental class III malocclusion.

\section{References}

[1]. Proffit WR. Fields HW, Sarver DM: Contemporary orthodontics. The Mosby Co. St: Louis. 2007. 
[2]. Sivamurthy G, Sundari S. Stress distribution patterns at mini-implant site during retraction and intrusion--a three-dimensional finite element study. Prog Orthod. 2016;17:4. Pubmed PMID: 26780464.

[3]. Nikopensius T, Saag M, Jagomägi T, Annilo T, Kals M, Kivistik PA, Milani L, Metspalu A. A missense mutation in DUSP6 is associated with Class III malocclusion. J Dent Res. 2013 Oct;92(10):893-8. Pubmed PMID: 23965468 .

[4]. Samantha C, Sundari S, Chandrasekhar S, Sivamurty G, Dinesh S. Comparative Evaluation of Two Bis-GMA Based Orthodontic Bonding Adhesives - A Randomized Clinical Trial. J Clin Diagn Res. 2017 Apr;11(4):ZC40ZC44. Pubmed PMID: 28571259.

[5]. Emrich RE, Brodie AG, Blayney JR. Prevalence of class I, class II, and class III malocclusions (angle) in an urban population an epidemiological study. Journal of dental research. 1965 Sep;44(5):947-53.

[6]. Hill IN, Blayney JR, Wolf W. The Evanston Dental Caries Study [Internet]. Vol. 38, Journal of Dental Research. 1959. p. 782-94. Available from:

[7]. El-Mangoury NH, Mostafa YA. Epidemiologic panorama of dental occlusion. Angle Orthod. 1990 Fall;60(3):207-14. Pubmed PMID: 2202237.

[8]. Reyes BC, Baccetti T, McNamara JA Jr. An estimate of craniofacial growth in Class III malocclusion. Angle Orthod. 2006 Jul;76(4):577-84. Pubmed PMID: 16808562 .

[9]. Thilander B, Pena L, Infante C, Parada SS, de Mayorga C. Prevalence of malocclusion and orthodontic treatment need in children and adolescents in Bogota, Colombia. An epidemiological study related to different stages of dental development. Eur J Orthod. 2001 Apr;23(2):153-67. Pubmed PMID: 11398553

[10]. Staudt CB, Kiliaridis S. Different skeletal types underlying Class III malocclusion in a random population. Am J Orthod Dentofacial Orthop. 2009 Nov;136(5):715-21. Pubmed PMID: 19892290

[11]. Krishnan S, Pandian S, Kumar S A. Effect of bisphosphonates on orthodontic tooth movement-an update. J Clin Diagn Res. 2015 Apr;9(4):ZE01-5. Pubmed PMID: 26023659.

[12]. Vikram NR, Prabhakar R, Kumar SA, Karthikeyan MK, Saravanan R. Ball Headed Mini Implant. Journal of clinical and diagnostic research: JCDR. 2017 Jan;11(1):ZL02.

[13]. Kamisetty SK, Verma JK, Arun, Sundari S, Chandrasekhar S, Kumar A. SBS vs Inhouse Recycling Methods-An Invitro Evaluation. J Clin Diagn Res. 2015 Sep;9(9):ZC04-8. Pubmed PMID: 26501002.

[14]. Nakasima A, Ichinose M, Nakata S. Genetic and environmental factors in the development of so-called pseudo- and true mesiocclusions. Am J Orthod Dentofacial Orthop. 1986 Aug;90(2):106-16. Pubmed PMID: 3461703.

[15]. Viswanath A, Ramamurthy J, Dinesh SP, Srinivas A. Obstructive sleep apnea: awakening the hidden truth. Niger J Clin Pract. 2015 Jan-Feb;18(1):1-7. Pubmed PMID: 25511335

[16]. Felicita AS. Quantification of intrusive/retraction force and moment generated during en-masse retraction of maxillary anterior teeth using mini-implants: A conceptual approach. Dental Press J Orthod. 2017 SepOct;22(5):47-55. Pubmed PMID: 29160344.

[17]. Rubika J, Sumathi Felicita A, Sivambiga V. Gonial Angle as an Indicator for the Prediction of Growth Pattern [Internet]. Vol. 6, World Journal of Dentistry. 2015. p. 161-3. Available from:

[18]. Cakan DG, Ulkur F, Taner TU. The genetic basis of facial skeletal characteristics and its relation with orthodontics. Eur J Dent. 2012 Jul;6(3):340-5. Pubmed PMID: 22904665

[19]. Jain RK, Kumar SP, Manjula WS. Comparison of intrusion effects on maxillary incisors among mini implant anchorage, $\mathrm{j}$-hook headgear and utility arch. J Clin Diagn Res. 2014 Jul;8(7):ZC21-4. Pubmed PMID: 25177631.

[20]. Mavropoulos A, Kiliaridis S. Orthodontic literature: an overview of the last 2 decades. Am J Orthod Dentofacial Orthop. 2003 Jul;124(1):30-40. Pubmed PMID: 12867895.

[21]. Ramesh Kumar KR, Shanta Sundari KK, Venkatesan A, Chandrasekar S. Depth of resin penetration into enamel with 3 types of enamel conditioning methods: a confocal microscopic study. Am J Orthod Dentofacial Orthop. 2011 Oct;140(4):479-85. Pubmed PMID: 21967934.

[22]. Frazier-Bowers S, Rincon-Rodriguez R, Zhou J, Alexander K, Lange E. Evidence of linkage in a Hispanic cohort with a Class III dentofacial phenotype. J Dent Res. 2009 Jan;88(1):56-60. Pubmed PMID: 19131318.

[23]. Rwakatema DS, Nganga PM, Kemoli AM. Prevalence of malocclusion among 12-15-year-olds in Moshi, Tanzania, using Bjork's criteria. East Afr Med J. 2006 Jul;83(7):372-9. Pubmed PMID: 17089497.

[24]. Felicita AS. Orthodontic management of a dilacerated central incisor and partially impacted canine with unilateral extraction - A case report. Saudi Dent J. 2017 Oct;29(4):185-193. PMID: 29033530.

[25]. Felicita AS, Chandrasekar S, Shanthasundari KK. Determination of craniofacial relation among the subethnic Indian population: a modified approach - (Sagittal relation). Indian J Dent Res. 2012 May-Jun;23(3):305-12. Pubmed PMID: 23059564.
[26]. Jain AR. Prevalence of partial edentulousness and treatment needs in rural population of South India. World Journal of Dentistry. 2017 Jun;8(3):213 7.

[27]. Varghese SS, Ramesh A, Veeraiyan DN. Blended Module-Based Teaching in Biostatistics and Research Methodology: A Retrospective Study with Postgraduate Dental Students. J Dent Educ. 2019 Apr;83(4):445-450. Pubmed PMID: 30745352

[28]. Ashok V, Ganapathy D. A geometrical method to classify face forms. J Oral Biol Craniofac Res. 2019 Jul-Sep;9(3):232-235. Pubmed PMID: 31198677.

[29]. Padavala S, Sukumaran G. Molar Incisor Hypomineralization and Its Prevalence. Contemp Clin Dent. 2018 Sep;9(Suppl 2):S246-S250. Pubmed PMID: 30294152

[30]. Ke Y, Al Aboody MS, Alturaiki W, Alsagaby SA, Alfaiz FA, Veeraraghavan VP, Mickymaray S. Photosynthesized gold nanoparticles from Catharanthus roseus induces caspase-mediated apoptosis in cervical cancer cells (HeLa). Artif Cells Nanomed Biotechnol. 2019 Dec;47(1):1938-1946. Pubmed PMID: 31099261

[31]. Ezhilarasan D. Oxidative stress is bane in chronic liver diseases: Clinical and experimental perspective. Arab J Gastroenterol. 2018 Jun;19(2):56-64. Pubmed PMID: 29853428.

[32]. Krishnan RP, Ramani P, Sherlin HJ, Sukumaran G, Ramasubramanian A Jayaraj G, Don KR, Santhanam A. Surgical Specimen Handover from Operation Theater to Laboratory: A Survey. Ann Maxillofac Surg. 2018 JulDec;8(2):234-238. Pubmed PMID: 30693238.

[33]. Ezhilarasan D, Sokal E, Najimi M. Hepatic fibrosis: It is time to go with hepatic stellate cell-specific therapeutic targets. Hepatobiliary Pancreat Dis Int. 2018 Jun;17(3):192-197. Pubmed PMID: 29709350.

[34]. Pandian KS, Krishnan S, Kumar SA. Angular photogrammetric analysis of the soft-tissue facial profile of Indian adults. Indian J Dent Res. $2018 \mathrm{Mar}-$ Apr;29(2):137-143. Pubmed PMID: 29652003.

[35]. Ramamurthy JA, Mg V. Comparison of effect of Hiora mouthwash versus Chlorhexidine mouthwash in gingivitis patients: A clinical trial. Asian J Pharm Clin Res. 2018 Jul 7;11(7):84-8.

[36]. Gupta P, Ariga P, Deogade SC. Effect of Monopoly-coating Agent on the Surface Roughness of a Tissue Conditioner Subjected to Cleansing and Disinfection: A Contact Profilometric In vitro Study. Contemp Clin Dent. 2018 Jun;9(Suppl 1):S122-S126. Pubmed PMID: 29962776.

[37]. Vikram NR, Prabhakar R, Kumar SA, Karthikeyan MK, Saravanan R. Ball Headed Mini Implant. J Clin Diagn Res. 2017 Jan;11(1):ZL02-ZL03. Pubmed PMID: 28274084.

[38]. Paramasivam A, Vijayashree Priyadharsini J, Raghunandhakumar S. N6adenosine methylation (m6A): a promising new molecular target in hypertension and cardiovascular diseases. Hypertens Res. 2020 Feb;43(2):153154. Pubmed PMID: 31578458.

[39]. Palati S, Ramani P, Shrelin HJ, Sukumaran G, Ramasubramanian A, Don KR, Jayaraj G, Santhanam A. Knowledge, Attitude and practice survey on the perspective of oral lesions and dental health in geriatric patients residing in old age homes. Indian J Dent Res. 2020 Jan-Feb;31(1):22-25. Pubmed PMID: 32246676

[40]. Samuel SR, Acharya S, Rao JC. School Interventions-based Prevention of Early-Childhood Caries among 3-5-year-old children from very low socioeconomic status: Two-year randomized trial. J Public Health Dent. 2020 Jan;80(1):51-60. Pubmed PMID: 31710096.

[41]. Tang EL, Wei SH. Recording and measuring malocclusion: a review of the literature. American Journal of Orthodontics and Dentofacial Orthopedics. 1993 Apr 1;103(4):344-51.

[42]. Baccetti T, Reyes BC, McNamara JA Jr. Gender differences in Class III malocclusion. Angle Orthod. 2005 Jul;75(4):510-20. Pubmed PMID: 16097218.

[43]. Lew KK, Foong WC, Loh E. Malocclusion prevalence in an ethnic Chinese population. Aust Dent J. 1993 Dec;38(6):442-9. Pubmed PMID: 8110079.

[44]. Tang EL. The prevalence of malocclusion amongst Hong Kong male dental students. Br J Orthod. 1994 Feb;21(1):57-63. Pubmed PMID: 8199166.

[45]. Soh J, Sandham A, Chan YH. Malocclusion severity in Asian men in relation to malocclusion type and orthodontic treatment need. Am J Orthod Dentofacial Orthop. 2005 Nov;128(5):648-52. Pubmed PMID: 16286213.

[46]. Steigman S, Kawar M, Zilberman Y. Prevalence and severity of malocclusion in Israeli Arab urban children 13 to 15 years of age. Am J Orthod. 1983 Oct:84(4):337-43. Pubmed PMID: 6578684.

[47]. Dinesh SP, Arun AV, Sundari KK, Samantha C, Ambika K. An indigenously designed apparatus for measuring orthodontic force. J Clin Diagn Res. 2013 Nov;7(11):2623-6. Pubmed PMID: 24392423.

[48]. Felicita AS. Orthodontic extrusion of Ellis Class VIII fracture of maxillary lateral incisor - The sling shot method. Saudi Dent J. 2018 Jul;30(3):265269. Pubmed. PMID: 29942113.

[49]. Borzabadi-Farahani A, Borzabadi-Farahani A, Eslamipour F. Malocclusion and occlusal traits in an urban Iranian population. An epidemiological study 
of 11- to 14-year-old children. Eur J Orthod. 2009 Oct;31(5):477-84. Pubmed PMID: 19477970.

[50]. Lundström A, Lundström O. A dental examination of the mixed and permanent dentitions in a Nubian population. Acta Odontol Scand. 1969 Aug;27(4):371-86. Pubmed PMID: 5257755.

[51]. Vijayashree Priyadharsini J. In silico validation of the non-antibiotic drugs acetaminophen and ibuprofen as antibacterial agents against red complex pathogens. J Periodontol. 2019 Dec;90(12):1441-1448. Pubmed PMID: 31257588.

[52]. J PC, Marimuthu T, C K, Devadoss P, Kumar SM. Prevalence and measurement of anterior loop of the mandibular canal using CBCT: A cross sectional study. Clin Implant Dent Relat Res. 2018 Aug;20(4):531-534. Pubmed PMID: 29624863.

[53]. Ramesh A, Varghese S, Jayakumar ND, Malaiappan S. Comparative estimation of sulfiredoxin levels between chronic periodontitis and healthy patients - A case-control study. J Periodontol. 2018 Oct;89(10):1241-1248. Pubmed PMID: 30044495.

[54]. Ramadurai N, Gurunathan D, Samuel AV, Subramanian E, Rodrigues SJL. Effectiveness of 2\% Articaine as an anesthetic agent in children: randomized controlled trial. Clin Oral Investig. 2019 Sep;23(9):3543-3550. Pubmed PMID: 30552590

[55]. Sridharan G, Ramani P, Patankar S, Vijayaraghavan R. Evaluation of salivary metabolomics in oral leukoplakia and oral squamous cell carcinoma. J Oral Pathol Med. 2019 Apr;48(4):299-306. Pubmed PMID: 30714209.
[56]. Ezhilarasan D, Apoorva VS, Ashok Vardhan N. Syzygium cumini extract induced reactive oxygen species-mediated apoptosis in human oral squamous carcinoma cells. J Oral Pathol Med. 2019 Feb;48(2):115-121. Pubmed PMID: 30451321.

[57]. Mathew MG, Samuel SR, Soni AJ, Roopa KB. Evaluation of adhesion of Streptococcus mutans, plaque accumulation on zirconia and stainless steel crowns, and surrounding gingival inflammation in primary molars: randomized controlled trial. Clin Oral Investig. 2020 Sep;24(9):3275-3280. Pubmed PMID: 31955271.

[58]. Samuel SR. Can 5-year-olds sensibly self-report the impact of developmental enamel defects on their quality of life? Int J Paediatr Dent. 2021 Mar;31(2):285-286. Pubmed PMID: 32416620.

[59]. R H, Ramani P, Ramanathan A, R JM, S G, Ramasubramanian A, K M. CYP2 C9 polymorphism among patients with oral squamous cell carcinoma and its role in altering the metabolism of benzo[a]pyrene. Oral Surg Oral Med Oral Pathol Oral Radiol. 2020 Sep;130(3):306-312. Pubmed PMID: 32773350.

[60]. Chandrasekar R, Chandrasekhar S, Sundari KKS, Ravi P. Development and validation of a formula for objective assessment of cervical vertebral bone age. Prog Orthod. 2020 Oct 12;21(1):38. Pubmed PMID: 33043408.

[61]. Vijayashree Priyadharsini J, Smiline Girija AS, Paramasivam A. In silico analysis of virulence genes in an emerging dental pathogen A. baumannii and related species. Arch Oral Biol. 2018 Oct;94:93-98. Pubmed PMID: 30015217. 